\title{
Bioedusiana
}

Blölogy

Education

Department

Universitas Siliwang

http://jurnal.unsil.ac.id/index.php/bioed

DOI: https://doi.org/10.37058/bioed.v6i2.3251

\section{Pengembangan Instrumen Tes Literasi Sains Berbasis Kontekstual pada Materi Pencemaran Lingkungan}

\section{Development of Contextual-Based Science Literacy Test Instruments on Environmental Pollution Materials}

\author{
Ayu Asri Martinah ${ }^{1 *}$, Velly Mubarok ${ }^{2}$, Mieke Miarsyah $^{3}$, Rizhal Hendi Ristanto ${ }^{4}$ \\ 1,2,3,4 Program Studi Magister Pendidikan Biologi, FMIPA, Universitas Negeri Jakarta, J1. Rawa Mangun \\ Muka Raya No.11, Rawamangun, Kec. Pulo Gadung, Kota Jakarta Timur, DKI Jakarta 13220, \\ Indonesia
}

\begin{abstract}
Abstrak
Kemampuan literasi sains siswa di Indonesia masih berada pada peringkat rendah berdasarkan pemeringkatan Programme for International Student Assessment (PISA). Kemampuan literasi sains sangat dibutuhkan oleh setiap orang guna menjalankan berbagai aktifitas kehidupan dengan mengaplikasikan pemahaman sains, mengaktualisasikan dan mengorganisasikan alam serta bersikap bijak pada alam semesta. Oleh karena itu diperlukan asesmen literasi sains yang berbasis kontekstual, sehingga siswa dapat berlajar mengimplementasikan pengetahuan sains pada kasus-kasus yang ada pada kehidupannya. Tujuan penelitian ini adalah untuk mengkaji kelayakan dan kualitas instrumen literasi sains berbasis kontekstual pada materi pencemaran lingkungan serta mengetahui validitas empiris dari instrumen yang di kembangkan. Penelitian pengembangan literasi sains dilakukan dengan menggunakan metode 4-D dengan 4 tahapan meliputi, define, design, develop, dan disseminate. Subjek penelitian ini yaitu siswa SMP Kartika-X dan siswa SMP PGRI 3 Bekasi yang berjumlah 70 siswa.Validitas logis divalidasi oleh dua validator ahli dan validitas empirik diujicobakan ke siswa. Validitas soal memperoleh hasil $70 \%$ yang berarti soal dikategorikan valid, reliabilitas memperoleh skor 0,74 yang berarti reliabel, dan terdapat 30\% soal dengan kategori sedang (tidak sukar dan tidak mudah) serta 19 soal dengan daya beda yang baik.
\end{abstract}

Kata kunci: Kemampuan literasi sains; Pengembangan Instrumen berbasis kontekstual; Metode 4-D

\section{Abstract}

The scientific literacy ability of students in Indonesia is still at a low rank based on Programme for International Student Assessment (PISA) results; everyone needs scientific literacy skills to carry out various life activities by applying scientific understanding, actualizing and organizing nature and being wise in the universe. Therefore a literacy assessment is needed. Contextual-based science so that students can implement scientific knowledge in cases that exist in their lives; The purpose of this study, the purpose of this study, to examine the feasibility and quality of contextual-based scientific literacy instruments on environmental pollution materials and to determine the empirical validity of the instruments developed; Scientific literacy development research is carried out using the 4-D method with 4 stages including, define, design, develop, and disseminate. The subjects of this study were students of SMP Kartika-X and SMP PGRI 3 Bekasi, totalling 70 students. Two expert validators validated content validity, and construct validity were tested by students. The validity of the questions obtained results of $70 \%$, which means it is said to be valid. Reliability gets a score of 0.74 , which means reliable. There are $30 \%$ of questions in the medium category (not difficult and not easy) and 19 questions with good distinguishing power.

Keywords: Scientific literacy ability; Contextual-based Instrument Development; 4-D Method

\section{Article History}

Received: July 2 $2^{\text {nd }}, 2021 ;$ Accepted: August 29 $9^{\text {th }}, 2021$; Published: December $31^{\text {st }}, 2021$

Corresponding Author*

Ayu Asri Martinah, Program Studi Magister Pendidikan Biologi FMIPA Universitas Negeri Jakarta, asriay18@gmail.com 


\section{PENDAHULUAN}

Dunia saat ini telah memasuki abad 21 yang berada pada perkembangan teknologi informasi berkembang dengan sangat pesat. Demi menghadapi abad ini seluruh manusia dituntut untuk memiliki berbagai kompetensi agar mampu bersaing, bertahan, dan beradaptasi dengan pesatnya perkembangan zaman. Pendidikan menjadi wadah awal dalam pembentukan karakter (Chusnani, 2013) dan kompetensi yang diperlukan oleh setiap individu agar dapat menjalankan proses kehidupannya dengan baik, utamanya agar dapat menyesuaikan diri dengan perkembangan zaman. Kurikulum Pendidikan nasional telah meningkatkan capaian-capaian kompetensi bagi siswanya sehingga selaras dengan tuntutan zaman seperti pendidikan karakter, higher order thingking skill (HOTS), dan literasi (Adawiyah \& Wisudawati, 2017).

Literasi menjadi salah satu hal yang penting dimiliki oleh setiap individu karena seiring dengan perkembangan ilmu pengetahuan dan teknologi maka diperlukan kesadaran, wawasan, dan sikap yang terintegrasi dengan pengetahuan sains sehingga semua orang dapat menjadi pakar sains (Glick \& Greenberg, 2017). Artinya, setiap individu hidup dan melakukan aktivitas kehidupan berdasarkan pemahaman sains yang dimilikinya. Pada beberapa kasus warga negara dan ilmuwan sering tidak setuju pada berbagai masalah yang berhubungan dengan sains, seperti keamanan makanan yang dimodifikasi secara genetik, perlunya vaksinasi, efek aktivitas manusia terhadap perubahan iklim, dan teori evolusi (Berman \& Kuden, 2017). Oleh karena itu perlunya penekanan terkait pemahaman sains dan aplikasinya dalam kehidupan.

Hazen (2002) menyatakan bahwa literasi sains cukup sederhana yaitu merupakan campuran konsep, sejarah, dan filsafat yang membantu memahami masalah ilmiah zaman ini. Literasi sains juga diartikan sebagai pengetahuan dan pemahaman tentang konsep dan proses ilmiah yang diperlukan untuk pengambilan keputusan pribadi, partisipasi dalam urusan sipil dan budaya, serta produktivitas ekonomi (Holbrook \& Rannikmae, 2009; Turiman et al., 2012). Secara defisit literasi sains didefinisikan sebagai anggapan bahwa masyarakat umum tidak memiliki pengetahuan yang memadai tentang sains dan oleh karena itu perlu dididik dengan lebih baik tentang dasar-dasar proses dan metode ilmiah untuk memahami bagaimana sains bekerja (Sutrisna, 2021). Proses penanaman dasar-dasar konseptual dan prosedural sains dapat diterapkan dalam dunia Pendidikan (Asyhari, 2015). Sains merupakan ilmu yang memahami, membangun, mengaktualisasikan dan mengorganisasikan alam semesta. Akan tetapi pada era ini, sains bukan hanya untuk memahami alam semesta melainkan untuk mengolah, menjaga dan berprilaku bijak terhadap alam semesta (Setiawan, 2019).

Chiappetta et al., (1991) menyatakan bahwa ada empat kategori literasi ilmiah meliputi ilmu pengetahuan sebagai badan pengetahuan, ilmu pengetahuan sebagai cara berpikir, ilmu pengetahuan sebagai cara menyelidiki, dan interaksi antara sains, teknologi, dan masyarakat. (Sulistiawati, 2015) memperluas catogory literasi ilmu pengetahuan pada interaksinya dengan 
lingkungan. Literasi sains memainkan peran penting dalam kehidupan sehari-hari manusia. Promosi literasi sains telah diakui sebagai tujuan utama pendidikan sains di dunia (BouJaoude, 2002). Ózdem et al., (2010) dalam studi mereka mencari hampir ratusan publikasi untuk menggambarkan karakteristik individu yang melek sains dan sebagai hasilnya mereka menyatakan bahwa individu yang melek sains harus memiliki pemahaman tentang konsep dasar sains, sifat sains, etika yang mengontrol ilmuwan dalam karyanya, keterkaitan sains dan masyarakat, keterkaitan sains dan humaniora, dan, perbedaan sains dan teknologi.

Literasi sains menurut Programme for International Student Assessment (PISA) diartikan sebagai kemampuan individu dalam menggunakan pengetahuan, mengidentifikasi permasalahan, menganalisis suatu fenomena, serta menarik kesimpulan dari bukti-bukti yang ada berkenaan dengan prilaku dan pengambilan keputusan terhadap alam (OECD, 2020). PISA merupakan ajang penilaian berskala internasional bagi literasi sains, yang diselenggarakan oleh Organization for Economic Cooperation and Development (OECD) yang diselenggarakan sejak tahun 2000 (Sellar \& Lingard, 2014). Indonesia sudah mengikuti program penilaian ini sejak tahun 2000, akan tetapi hingga saat ini Indonesia masih berada pada tingkat rendah untuk kemampuan literasi sains (Mullis et al., 2012) Peringkat literasi sains Indonesia sejak 2000 - 2018 disajikan dalam Tabel 1.

Tabel 1. Peringkat Literasi Sains Indonesia dalam PISA

\begin{tabular}{cccc}
\hline Tahun & $\begin{array}{c}\text { Skor Rata-rata } \\
\text { Indonesia }\end{array}$ & Peringkat Indonesia & $\begin{array}{c}\text { Jumlah Negara Peserta } \\
\text { Tes }\end{array}$ \\
\hline 2000 & 393 & 38 & 41 \\
2003 & 395 & 38 & 40 \\
2006 & 393 & 50 & 57 \\
2009 & 383 & 60 & 65 \\
2012 & 382 & 64 & 65 \\
2015 & 402 & 62 & 70 \\
2018 & 382 & 71 & 77 \\
\hline
\end{tabular}

(Sumber: diambil dan diolah dari hasil laporan PISA)

Demi meningkatkan kemampuan literasi sains siswa Indonesia maka diperlukan orientasi kurikulum terkait literasi, dukungan sekolah dan siswa, serta pengembangan instrument penilaian literasi sains. Penilaian atau evaluasi merupakan suatu alat yang digunakan untuk mengukur ketercapain tujuan pembelajaran (Fraenkel et al., 2009). Pengembangan instrumen penilaian literasi sains dilakukan agar siswa dapat terlatih dalam mengejakan soal ataupun menyelesaikan masalah di kehidupan dengan mengaplikasikan sains. Upaya untuk melatih literasi sains siswa juga dapat di rancang dalam instrument soal berbasis kontekstual yang ditemukan siswa pada kehidupan nyata (Fensham, 2009). Pengembangan instrumen berbasis literasi sains ini memiliki empat dimensi yang dapat diteliti dan dijadikan sebagai acuan pengembangan, meliputi; konten sains, proses sains, aplikasi sains dan sikap bijak terhadap sains (OECD, 2016). 
Berdasarkan uraian tersebut, penelitian ini bertujuan untuk mengkaji kelayakan dan kualitas instrumen literasi sains berbasis kontekstual pada materi pencemaran lingkungan serta mengetahui validitas empiris dari instrumen yang di kembangkan. Rancangan soal disusun berdasarkan indikator domain kompetensi literasi saintifik dari kerangka kerja PISA (OECD, 2016). Indikator tersebut dikaitkan dengan topik pencemaran lingkungan. Karena itu, rumusan masalah yang menjadi fokus penelitian ini ialah, "Bagaimana kelayakan dan kualitas instrumen literasi sains berbasis kontekstual pada materi pencemaran lingkungan?".

\section{METODE}

Jenis penelitian ini yaitu penelitian dan pengembangan. Putrawan, (2021) menyebutkan bahwa jenis penelitian pengembangan merupakan salah satu penelitian yang bertujuan untuk meningkatkan sesuatu dalam hal ini yaitu literasi sains siswa. Metode yang digunakan dalam penelitian ini yaitu metode pengembangan 4-D (Thiagarajan, S. et al., 1974) yang terdiri dari 4 tahapan yaitu, define, design, develop, dan disseminate. Akan tetapi pada penelitian ini hanya tiga tahapan yang terlaksana yaitu define, design, dan develop. Tahapan disseminate tidak terlaksana karena terkendala oleh waktu dan kondisi akibat pandemic Covid-19. Dalam setiap tahapan terdiri dari beberapa langkah yang kami lakukan, Langkah tersebut dapat dilihat pada Gambar 1.
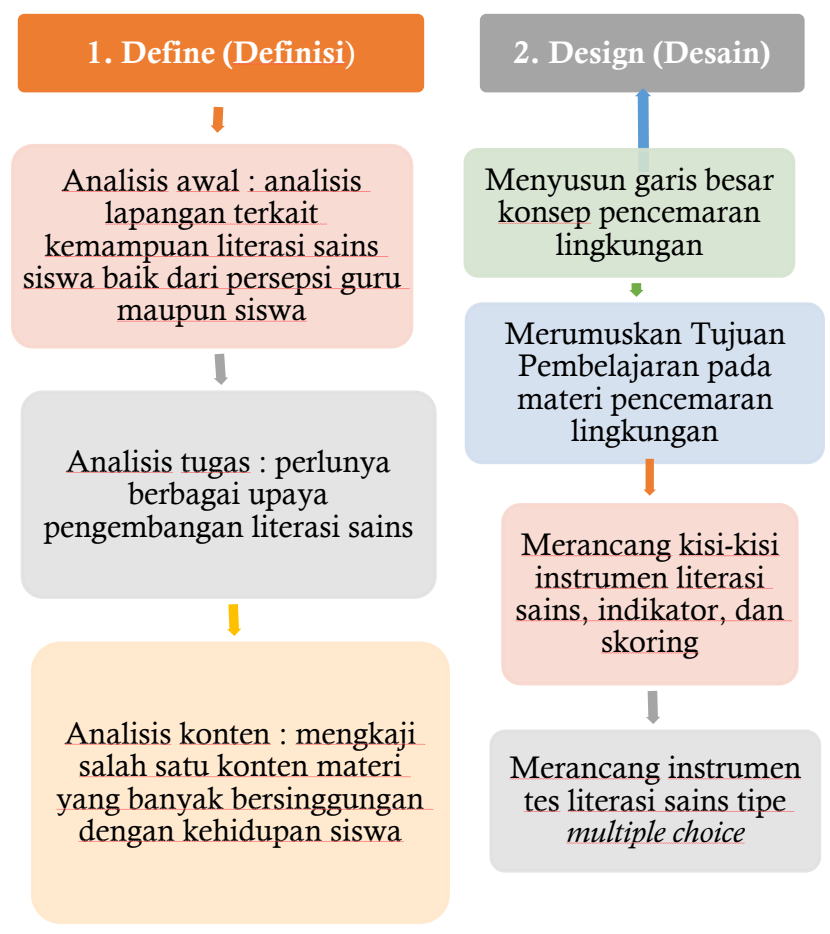

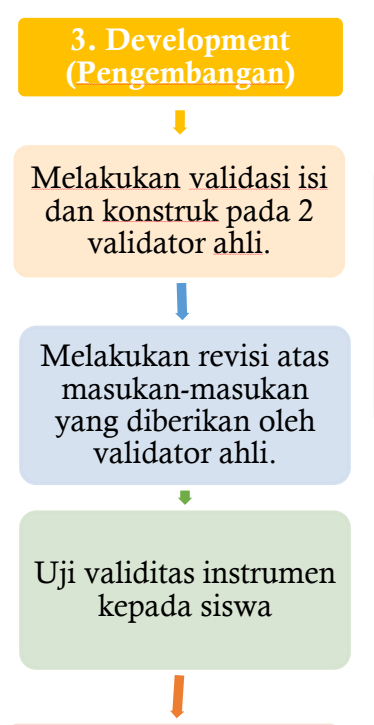

Diperoleh 30 soal valid

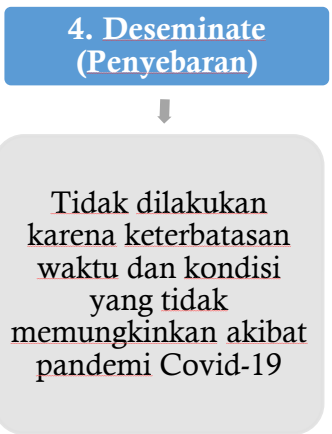

Gambar 1. Tahapan penelitian 


\section{Tempat dan Waktu Penelitian}

Penelitian ini dilakukan di SMP Kartika X-1 dan SMP PGRI 3 Kota Bekasi diujikan ke kelas VIII. Waktu penelitian yaitu 14 Juni 2021 dengan waktu pengerjaan 60 menit untuk 30 soal via google formulir.

\section{Populasi dan Sampel}

Populasi penelitian ini adalah siswa SMP Kartika X-1 dan siswa SMP PGRI 3 Kota Bekasi tahun pelajaran 2020 - 2021. Sampel dalam penelitian ini menggunakan purposive sampling dengan pertimbangan siswa yang sudah mendapatkan materi pelajaran. Jumlah sampel yakni sebanyak 35 siswa SMP Kartika X-1 kelas VIII dan 35 siswa SMP PGRI 3 Kota Bekasi kelas VIII.

\section{Instrumen Penelitian dan Teknis Analisis Data}

Instrument penelitian yang digunakan pada penelitian ini terdiri dari dua, yaitu:

1. Pengujian kelayakan instrumen butir soal yang dikembangkan dengan menggunakan uji validasi kepada validator ahli yang akan membuktikan validitas subtansi, konstruksi dan Bahasa. Kisi-kisi validasi oleh ahli dijabarkan pada Tabel 2.

Tabel 2. Kisi-kisi Validasi Instrumen oleh Ahli

\begin{tabular}{ll}
\hline Dimensi & \multicolumn{1}{c}{ Indikator } \\
\hline Substansi & Sesuai dengan indikator dalam kisi - kisi penyusunan soal \\
& Indikator yang diujikan sudah dipilih sesuai dengan dimensi literasi PISA \\
\hline Konstruksi & Opsi/pengecoh berfungsi \\
& Hanya ada satu jawaban yang benar \\
& Soal tidak mengandung pernyataan negatif \\
& Soal tidak mengarah ke jawaban yang benar \\
& Option homogen dan logis dilihat dari segi materi \\
& Option tidak mengandung statement semua jawaban benar atau salah \\
& Gambar, tabel, diagram, dan grafik menstimulus dinyatakan dengan jelas dan berfungsi \\
& dengan baik \\
& Butir soal tidak bergantung kepada jawaban soal sebelumnya \\
& Menggunakan bahasa indonesia dengan baik dan benar \\
& Bahasa yang digunakan komunikatif \\
& Tidak menggunakan bahasa yang berlaku setempat/tabu \\
& Pilihan jawaban tidak mengulang kata/kelompok kata sama, kecuali merupakan satu \\
kesatuan pengertian
\end{tabular}

2. Melakukan uji coba instrument butir soal yang telah dikembangkan kepada siswa SMP kelas VIII dan menganalisis skor yang dihasilkan untuk mendapatkan kelayakan instrumen butir soal yang dikembangkan. Instrument Literasi yang dikembangkan mengacu pada OECD, (2016) terdiri dari 30 soal yang dijabarkan pada Tabel 3. 
Tabel 3. Kisi-Kisi Instrumen Literasi Sains

\begin{tabular}{lll}
\hline \multicolumn{1}{c}{ Dimensi Literasi Sains } & \multicolumn{1}{c}{ Indikator } & \multicolumn{1}{c}{ Nomor Butir } \\
\hline Pengetahuan sains & Pengetahuan konten & $1^{*}, 2,3,4^{*}, 8,12$ \\
& Pengetahuan procedural & $5^{*}, 6,7^{*}, 9$ \\
Proses sains & Menjelaskan fenomena ilmiah & 10,11 \\
& Menafsirkan data dan bukti ilmiah & $13,14,15^{*}, 16,17,21,22$ \\
Konteks aplikasi sains & Personal & $18,19^{*}, 20$ \\
& Lingkungan & $23,24^{*}, 25,26$ \\
Sikap & Kesadaran lingkungan & $27,28,29,30$ \\
\hline
\end{tabular}

Ket: $\left({ }^{*}\right)$ soal tidak valid

\section{Teknik Analisis Data}

1. Analisis Logis

Analisis berdasarkan pada saran atau hasil validasi dari validator ahli. Penelitian ini menggunakan instrument validasi dengan skoring polytomy 5-4-3-2-1. Untuk menghitung instrument validasi dengan menggunakan rumus persentase hasil sebagai berikut:

$$
\text { Validitas }(V)=\frac{\text { Total skor } 2 \text { validasi ahli }}{\text { Total skor maksimal }} \times 100 \%
$$

Hasil validitas instrument selanjutnya dicocokkan dengan tabel kriteria kelayakan seperti pada Tabel 4, yang merujuk Akbar, (2013).

Tabel 4. Kriteria Kelayakan

\begin{tabular}{cc}
\hline Skor dalam persen (\%) & Kategori Kelayakan \\
\hline$<21 \%$ & Sangat tidak layak \\
$21-40 \%$ & Tidak layak \\
$41-60 \%$ & Cukup layak \\
$61-80 \%$ & Layak \\
$81-100 \%$ & Sangat layak \\
\hline
\end{tabular}

2. Analisis Empiris

a. Validitas menggunakan rumus Point-biseral

Keterangan:

$$
\gamma p b i \frac{M p-M t}{S t} \sqrt{\frac{p}{q}}
$$

$$
\begin{array}{ll}
\gamma_{p b i s} & =\text { Koefisien korelasi point biserial } \\
M_{p} & =\text { Rata }- \text { rata skor total yang menjawab benar pada butir soal } \\
M_{t} & =\text { Rata }- \text { rata skor total } \\
S_{t} & =\text { Standar deviasi skor total } \\
p & =\text { Proporsi siswa yang menjawab benar pada setiap butir soal } \\
q & =\text { proporsi siswa yang menjawab salah pada setiap butir soal }
\end{array}
$$

b. Perhitungan Koefisien Reliabilitas menggunakan rumus KR-20

$$
r 11\left(\frac{n}{n-1}\right)\left(\frac{s^{2}-\sum p q}{s^{2}}\right)
$$


Keterangan:

$\mathrm{r}_{11} \quad=$ reliabilitas tes secara keseluruhan

$S^{2} \quad=$ varian

$k=$ banyaknya item

$p \quad=$ proporsi subjek yang menjawab item dengan benar

$q \quad=$ proporsi subjek yang menjawab item dengan salah

$\sum p q \quad=$ jumlah hasil kali $\mathrm{p}$ dan $\mathrm{q}^{24}$

Interpretasi hasil hitung koefisien reliabilitas seperti menghitung koefisien determinasi dalam korelasi. Sebagai contoh hasil perhitungan koefisien reliabilitas, baik menggunakan alpha Cronbach, maupun dengan KR-20/21, diperoleh koefisien reliabilitas sebesar 0,70 maka koefisien ini di kuadratkan lalu dikalikan 100\% sehingga di peroleh $49 \%$ responden menilai instrument yang dikembangkan dapat dipercaya (reliabel) (Putrawan, 2021)

c. Taraf Kesukaran

Instrument butir soal yang baik merupakan soal yang tidak mudah atau tidak terlalu sukar (Arikunto, 2019).

Keterangan:

$$
\mathrm{P}=\frac{B}{J S}
$$

$\mathrm{P} \quad=$ indeks kesukaran

$\mathrm{B} \quad$ = banyaknya siswa menjawab benar

JS $\quad=$ jumlah seluruh peserta tes

Hasil perhitungan taraf kesukaran soal selanjutnya dicocokkan dengan Tabel 5 klasifikasi indeks kesukaran yang diadaptasi dari (Nana, 2014).

Tabel 5. Klasifikasi Indeks Kesukaran

\begin{tabular}{cl}
\hline Indeks Tingkat Kesukaran (P) & \multicolumn{1}{c}{ Keterangan } \\
\hline $0,0-0,30$ & Sukar \\
$0,31-0,70$ & Sedang \\
$0,71-1,00$ & Mudah \\
\hline
\end{tabular}

d. Daya Pembeda

Daya pembeda berperan dalam mengukur sejauh mana siswa yang sudah menguasai materi dan siswa yang belum menguasai (Sugiyono, 2019; Zainal, 2012) Indeks diskriminasi berkisaran antara 0,00 sampai 1,0 tetapi ada tanda negative yang menunjukkan soal tersebut tidak memiliki daya pembeda.

$$
\mathrm{D}=\frac{B a}{J a}-\frac{B b}{J b}=\mathrm{P}_{\mathrm{A}}-\mathrm{P}_{\mathrm{B}}
$$

Hasil perhitungan daya pembeda soal, selanjutnya di cocokkan dengan Tabel 6 klasifikasi daya pembeda yang merujuk pada (Arikunto, 2019).

Tabel 6. Klasifikasi Daya beda

\begin{tabular}{cc}
\hline Klasifikasi Daya Beda & Keterangan \\
\hline $0,00-0,20$ & Jelek \\
$0,21-0,40$ & Cukup \\
\hline
\end{tabular}




$\begin{array}{cc}0,41-0,70 & \text { Baik } \\ 0,71-1,00 & \text { Baik Sekali }\end{array}$

\section{HASIL DAN PEMBAHASAN}

\section{Define (Definisi)}

Tahap pertama pada define di awali dengan analisis terkait kemampuan literasi sains siswa di SMP Kartika-X dan SMP PGRI 3 melalui wawancara dengan guru mata pelajaran yang bersangkutan, dari kedua SMP tersebut guru mengemukakan bahwa literasi sains siswa masih rendah serta sulitnya mengembangkan literasi sains siswa walaupun sudah ada program implementasi literasi sains dalam model, metode pembelajaran dan instrument pembelajaran. Program literasi yang biasa dilaksanakan sekolah pun kini terhambat dengan adanya pandemic covid-19. Rendahnya literasi sains siswa dapat disebabkan oleh beberapa factor seperti pemilihan bahan ajar, miskonsepsi, rendahnya kemampuan membaca, dan pembelajaran yang tidak kontekstual. Hal ini selaras dengan penelitian Fuadi et al., (2020) bahwa permasalahan pada pelajaran sains adalah persepsi siswa bahwa sains itu sulit, tidak di mengerti dan siswa merasa tidak perlu sains. Afriana et al., (2016) juga mengemukakan bahwa pada konteks aplikasi sains siswa masih belum bisa mengaitkan pengetahuan sains dengan fenomena yang terjadi di lingkungan sekitarnya. Oleh karena itu untuk meningkatkan literasi sains peserta didik kita perlu menambahkan aspek kontekstual dalam pembelajaran, seperti menggunakan instrument test literasi sains berbasis kontekstual sehingga siswa lebih memahami pentingnya sains dalam kehidupannya.

Tahap kedua yaitu analisis penugasan berdasarkan hasil analisis awal maka perlunya penugasan terkait pengembangan literasi sains di SMP Kartika-X dan SMP PGRI 3. Pengembangan yang digunakan yaitu pengembangan instrument soal dengan tujuan membiasakan siswa terhadap soal-soal bertipe literasi sehingga dengan pembiasaan ini dapat membantu siswa dalam menjawab berbagai persoalan di kehidupan nyata. Instrument literasi juga dapat digunakan untuk mengukur sejauh mana literasi sains siswa serta mengevaluasi kekurangan siswa dalam aspek literasi. Hal ini selaras dengan Septiani et al., (2019) bahwa instrument literasi dapat digunakan untuk mengukur dan meningkatkan kemampuan literasi sains siswa.

Tahap ketiga yaitu analisis konten, konten yang dipilih yaitu sub materi pencemaran lingkungan. Konten ini dipilih karena memiliki banyak muatan yang berkaitan erat dengan kehidupan siswa, lingkungan merupakan tempat tingal semua mahluk hidup termasuk siswa, maka segala bentuk perubahan dan kerusakan lingkungan akan berdampak pada kehidupan manusia. oleh karena itu siswa perlu memahami aspek lingkungan serta kaitannya dengan konteks sains sehingga siswa dapat memahami fenomena alam yang terjadi, mengetahui penyebab kerusakan lingkungan, menganalisis solusi terbaik bagi kerusakan lingkungan serta 
berperilaku literate dan bijak terhadap lingkungan. Selaras dengan hal ini Fibula Purnama et al., (2020) mengemukakan bahwa pemahaman terkait isu-isu lingkungan sangat penting untuk meningkatkan perilaku bertanggungjawab lingkungan.

\section{Design (Desain)}

Pada tahap desain konsep pencemaran lingkungan di gambarkan secara general melalui penjabaran $\mathrm{KD} 3.8$ yang diuraikan melalui indikator pencemaran lingkungan kemudian di susun dan disesuaikan dengan dimensi dan indikator dari literasi sains seperti yang terlihat pada Tabel 7. Selanjutnya setelah penyusunan kisi-kisi instrument soal, pada tahap desain juga terdapat penyusunan butir soal literasi sains yang terdapat pada Lampiran 1.

Tabel 7. Penyusunan Instrumen Soal berdasarkan Indikator Literasi dan Materi

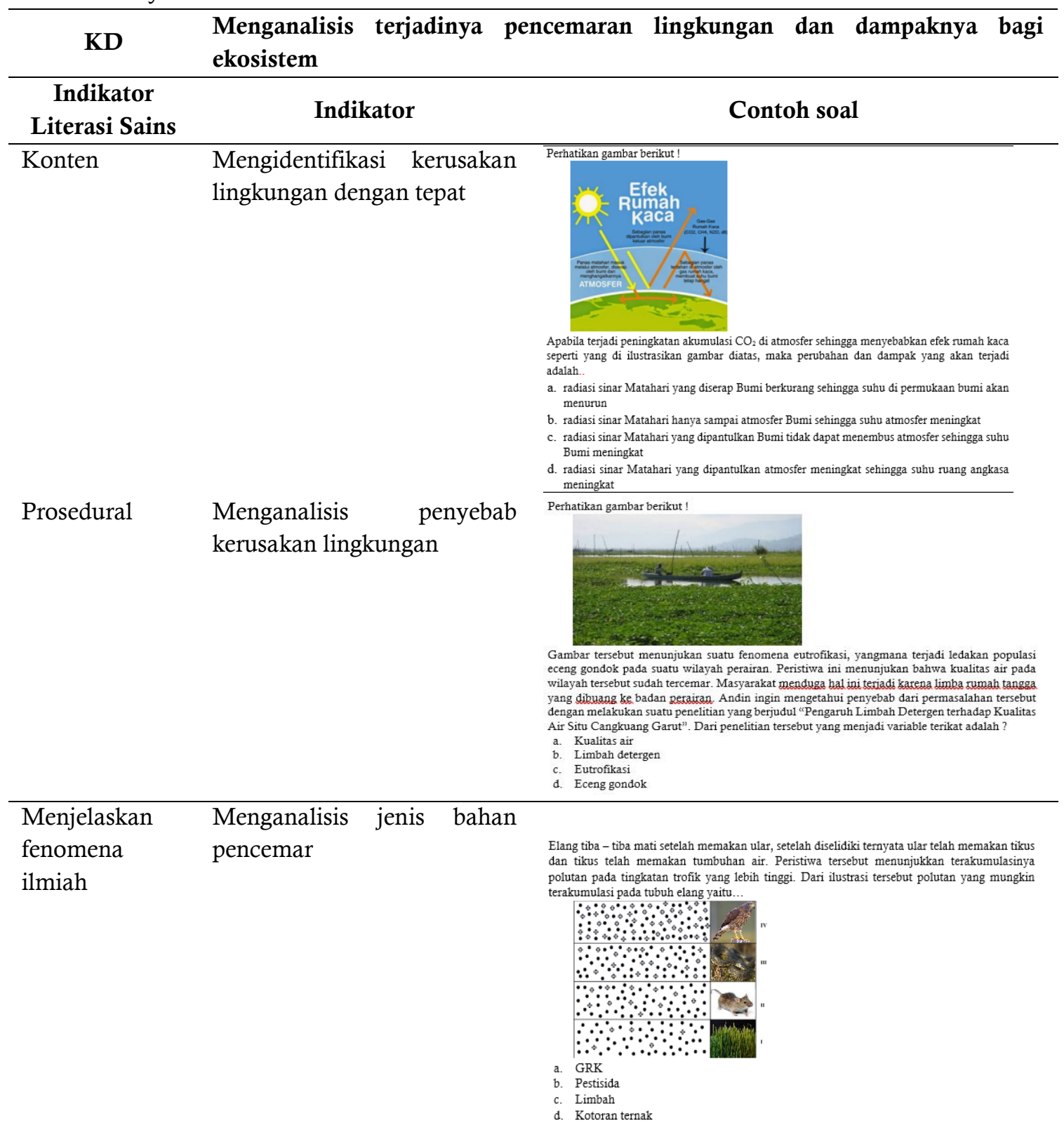




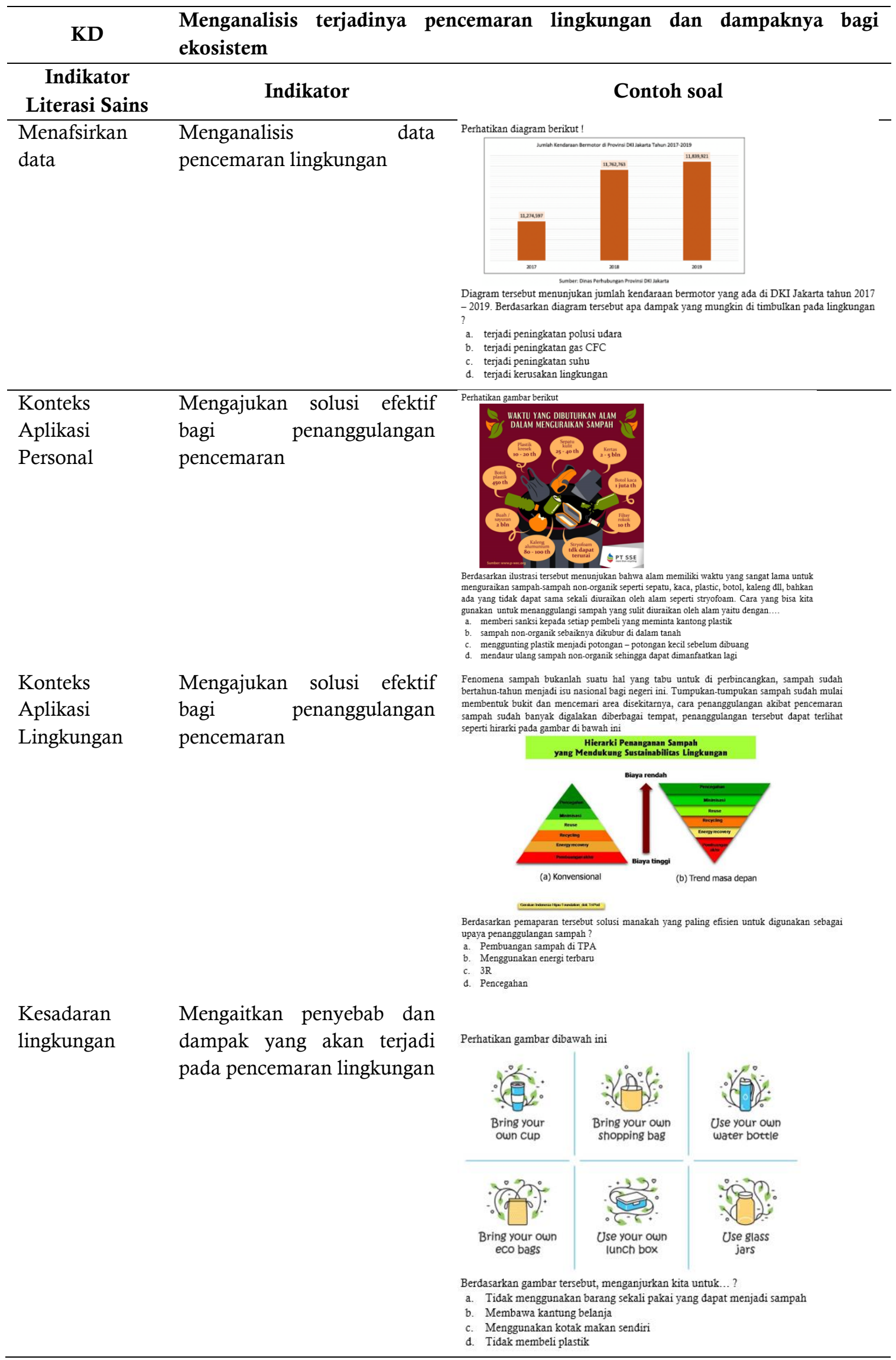




\section{Development (pengembangan)}

Pada tahap development instrument soal yang sudah di susun lalu dianalisis dengan dua tahapan yaitu analisis logis oleh 2 validator ahli dan analisis empiris melalui perhitungan validitas, reliabilitas butir soal serta uji taraf kesukaran dan daya pembeda untuk mengetahui kualitas dari butir soal yang dikembangkan.

\section{a. Validasi instrument oleh validator ahli}

Instrumen tes literasi sains dalam penelitian ini divalidasi dengan membuat lembar validasi instrument berdasarkan kisi - kisi instrument butir soal literasi sains. Instrument butir soal literasi dikonsultasikan ke validator ahli yaitu 1 dosen biologi dan 1 guru IPA bersertifikasi untuk mendapatkan saran dari para validator ahli. validasi oleh validator ahli meluputi 3 komponen utama yaitu substansi isi, konstruksi dan tata Bahasa, sejalan dengan (Ihsan, 2015) yang menyatakan bahwa validasi logis terdiri dari validitas isi, validitas konstruk, dan validitas kriteria perlu divalidasi oleh ahli untuk mendapatkan kriteria kelayakan yang sesuai. Hasil validasi tersebut dijabarkan pada Tabel 8.

Tabel 8. Hasil Validasi Instrumen oleh Validator Ahli

\begin{tabular}{|c|c|c|c|c|}
\hline Kriteria Penulisan & Validator 1 & Validator 2 & Persentase & Kriteria Nilai \\
\hline \multicolumn{5}{|l|}{ Syarat Substansi } \\
\hline $\begin{array}{l}\text { Sesuai dengan indikator dalam kisi - kisi } \\
\text { penyusunan soal }\end{array}$ & 4,03 & 4,15 & $82 \%$ & Sangat Layak \\
\hline $\begin{array}{l}\text { Indikator yang diujikan sudah dipilih } \\
\text { sesuai dengan dimensi literasi PISA }\end{array}$ & 4,07 & 4,20 & $83 \%$ & Sangat Layak \\
\hline \multicolumn{5}{|l|}{ Syarat Konstruksi } \\
\hline Opsi/pengecoh berfungsi & 3,83 & 3,83 & $77 \%$ & Layak \\
\hline Hanya ada satu jawaban yang benar & 4,00 & 3,90 & $79 \%$ & Layak \\
\hline $\begin{array}{l}\text { Soal tidak mengandung pernyataan } \\
\text { negatif }\end{array}$ & 4,47 & 4,45 & $89 \%$ & Sangat layak \\
\hline $\begin{array}{l}\text { Soal tidak mengarah ke jawaban yang } \\
\text { benar }\end{array}$ & 4,07 & 4,10 & $82 \%$ & Sangat Layak \\
\hline $\begin{array}{l}\text { Option homogen dan logis dilihat dari } \\
\text { segi materi }\end{array}$ & 4,27 & 4,15 & $84 \%$ & Sangat Layak \\
\hline $\begin{array}{l}\text { Option tidak mengandung statement } \\
\text { semua jawaban benar atau salah }\end{array}$ & 4,37 & 4,38 & $87 \%$ & Sangat Layak \\
\hline $\begin{array}{l}\text { Gambar, tabel, diagram, dan grafik } \\
\text { menstimulus dinyatakan dengan jelas } \\
\text { dan berfungsi dengan baik }\end{array}$ & 3,97 & 4,00 & $80 \%$ & Layak \\
\hline $\begin{array}{l}\text { Butir soal tidak bergantung kepada } \\
\text { jawaban soal sebelumnya }\end{array}$ & 4,37 & 4,40 & $88 \%$ & Sangat Layak \\
\hline \multicolumn{5}{|l|}{ Syarat Bahasa } \\
\hline $\begin{array}{l}\text { Menggunakan bahasa indonesia dengan } \\
\text { baik dan benar }\end{array}$ & 4,47 & 4,40 & $89 \%$ & Sangat Layak \\
\hline Bahasa yang digunakan komunikatif & 4,23 & 4,40 & $86 \%$ & Sangat Layak \\
\hline $\begin{array}{l}\text { Tidak menggunakan bahasa yang } \\
\text { berlaku setempat/tabu }\end{array}$ & 4,83 & 4,50 & $93 \%$ & Sangat Layak \\
\hline
\end{tabular}




\begin{tabular}{lcccc}
\hline \multicolumn{1}{c}{ Kriteria Penulisan } & Validator 1 & Validator 2 & Persentase & Kriteria Nilai \\
\hline $\begin{array}{l}\text { Pilihan jawaban tidak mengulang } \\
\text { kata/kelompok kata sama, kecuali } \\
\text { merupakan satu kesatuan pengertian }\end{array}$ & 4,00 & 4,10 & $81 \%$ & Sangat Layak \\
\hline Skor Rata-rata & & & & \\
\hline
\end{tabular}

Berdasarkan hasil perhitungan pada tabel 8, Kategori substansi mendapat kriteria nilai sangat layak artinya instrument sudah sesuai dengan indicator dan kisi-kisi serta selaras dengan dimensi literasi sains PISA. Kategori konstruksi mendapat kriteria nilai yang layak dan sangat layak, instrument yang dikembangkan tidak hanya didominasi oleh narasi, akan tetapi juga ada tabel, diagram, gambar, dan symbol sehingga siswa dapat lebih mudah memahami informasi yang di dapat. Kategori Bahasa mendapatkan kriteria sangat layak karena sudah menggunakan Bahasa Indonesia yang baik dan benar, komunikatif, jelas dan mudah dipahami. Hasil keseluruhan validitas logis oleh dua validator ahli menunjukkan skor rata-rata $84,2 \%$ yang mana berdasarkan tabel yang merujuk pada (Akbar, 2013) bahwa jika indeks validitas logis berada pada kriteria 81\%- 100\% berarti instrument tersebut dalam kategori sangat layak untuk digunakan dan diuji coba.

Instrument soal yang telah melalui tahap validasi oleh dua validator selanjutnya direvisi berdasarkan komentar dan saran yang diberikan oleh validator ahli. Berikut saran yang diberikan oleh para validator ahli terkait kevalidan instrument butir soal literasi sains dapat di lihat pada Tabel 9.

Tabel 9. Komentar dan Saran Validator Ahli

\begin{tabular}{lll}
\hline \multicolumn{1}{c}{ Validator } & & \multicolumn{1}{c}{ Saran } \\
\hline Dr. Irdalisa, S.Si, M.Pd. & 1. & Perbaiki kisi - kisi dengan taksonomi kata kerja C4-C6 \\
& 2. & Perbaiki penulisan dan tata Bahasa yang tidak sesuai \\
Sawukirnadi, S.Pd & 1. & Perbaiki kisi - kisi dengan kata kerja analisis \\
& 2. & Sesuaikan kisi - kisi dengan dimensi literasi sains \\
\hline
\end{tabular}

Kedua validator ahli menekankan pada aspek substansi yaitu kesesuaian instrument dengan kisi-kisi, pemilihan kata dalam indikator, serta kesesuaian instrument dengan dimensi dan indikator literasi sains. Hal ini bertujuan untuk meningkatkan kualitas instrument yang dikembangkan.

\section{b. Uji Coba Instrumen Butir Soal}

Instrumen butir soal pada materi pencemaran lingkungan dirancang berdasarkan indikator dimensi - dimensi literasi sains, kemudian di uji coba kan untuk mengetahui hasil pengujian validitas, perhitungan reliabilitas, tingkat kesukaran dan daya pembeda dengan menggunakan validasi butir dihitung menggunakan rumus point-biserial pada saat uji coba menggunakan sekitar $n=70$, kemudian diuji menggunakan uji $r$ tabel pada $\alpha=$ 
0,05, karena skoringnya dichotomy ( 1 untuk jawaban benar dan 0 bagi jawaban yang salah). Apabila $\mathrm{r}_{\text {-hitung }}<\mathrm{r}$-tabel, maka butir dibuang karena tidak valid.

1) Hasil Pengujian Validitas

Hasil pengujian validitas instrument butir soal di jabarkan pada Tabel 10.

Tabel 10. Hasil Pengujian Validitas Instrumen Soal Literasi Sains

\begin{tabular}{|c|c|c|c|}
\hline \multirow{2}{*}{ No. } & \multicolumn{3}{|c|}{ Validitas } \\
\hline & $\mathbf{r}_{\mathrm{xy}}$ & Rtabel 0,05 & Keterangan \\
\hline 1 & 0,099 & 0,235 & Tidak valid \\
\hline 2 & 0,263 & 0,235 & Valid \\
\hline 3 & 0,305 & 0,235 & Valid \\
\hline 4 & 0,117 & 0,235 & Tidak valid \\
\hline 5 & $-0,046$ & 0,235 & Tidak valid \\
\hline 6 & 0,245 & 0,235 & Valid \\
\hline 7 & 0,206 & 0,235 & Tidak valid \\
\hline 8 & 0,613 & 0,235 & Valid \\
\hline 9 & 0,285 & 0,235 & Valid \\
\hline 10 & 0,328 & 0,235 & Valid \\
\hline 11 & 0,386 & 0,235 & Valid \\
\hline 12 & 0,468 & 0,235 & Valid \\
\hline 13 & 0,474 & 0,235 & Valid \\
\hline 14 & 0,344 & 0,235 & Valid \\
\hline 15 & 0,100 & 0,235 & Tidak valid \\
\hline 16 & 0,379 & 0,235 & Valid \\
\hline 17 & 0,451 & 0,235 & Valid \\
\hline 18 & 0,372 & 0,235 & Valid \\
\hline 19 & 0,233 & 0,235 & Tidak valid \\
\hline 20 & 0,343 & 0,235 & Valid \\
\hline 21 & 0,270 & 0,235 & Valid \\
\hline 22 & 0,566 & 0,235 & Valid \\
\hline 23 & 0,574 & 0,235 & Valid \\
\hline 24 & 0,231 & 0,235 & Tidak valid \\
\hline 25 & 0,251 & 0,235 & Valid \\
\hline 26 & 0,651 & 0,235 & Valid \\
\hline 27 & 0,396 & 0,235 & Valid \\
\hline 28 & 0,573 & 0,235 & Valid \\
\hline 29 & 0,268 & 0,235 & Valid \\
\hline 30 & 1 & 0,235 & Valid \\
\hline
\end{tabular}

Pada taraf $\alpha=0,05$ dengan $n=70$ diperoleh $r_{\text {tabel }}=0,235$ dari tabel terlihat bahwa dalam setiap butir soal koefisien $\mathrm{r}_{\text {hitung }}\left(\mathrm{r}_{\mathrm{xy}}\right)$ lebih besar dari $\mathrm{r}_{\text {tabel }}$ kecuali nomor 1, 4, 5, 7, 15, 19, dan 24 karena tidak valid, sehingga soal tidak dapat digunakan. Maka butir soal nomor 2, 3, 6, 8, 9, 10, 11, 12, 13, 14, 16, 17, 18, 20, 21, 22, 23, 25, 26, 27, 28, 29, dan 30 dinyatakan valid dan dapat digunakan. Dapat dikatakan terdapat 23 soal yang valid 
atau sekitar 76,67\%. Sejalan dengan penelitian (Septiani et al., 2019) yang menyatakan bahwa pengembangan instrument yang melebihi batas validitas $70 \%$ maka dikategorikan sebagai instrument yang baik. Uji validitas ini dilakukan dengan tujuan untuk menilai alat ukur yang digunakan, apakah dapat menjalankan fungsinya dengan tepat, dan memiliki kecermatan yang baik.

2) Pengujian Reliabilitas

Pengujian reliabilitas suatu instrument ditujukan untuk melihat keandalan instrument yang dikembangkan. Hasil Perhitungan Koefisien Reliabilitas dihitung dengan rumus KR-20 dapat dilihat pada Tabel 11.

Tabel 11. Hasil perhitungan koefisien relianilitas

\begin{tabular}{ccc}
\hline Sum pq & Varians & Reliabilitas \\
\hline 5,70 & 19,89 & 0,74 \\
\hline
\end{tabular}

Hasil hitung koefisien reliabilitas dengan sampel uji coba sebanyak 70 orang dan butir soal 30 pertanyaan, yaitu sebesar 0,74 . Artinya responden memiliki tingkat kepercayaan terhadap instrument butir soal penelitian sebesar $(0,74)^{2} \times 100 \%=0,54 \%$. Sejalan dengan yang disampaikan oleh (Putrawan, 2021) bahwa instrument soal diatas 0,7 dapat dikatakan reliabel.

3) Tingkat Kesukaran

Pengujian ini dilakukan untuk mengetahui tingkat kesukaran instrument butir soal literasi sains dalam materi pencemaran lingkungan. Berdasarkan uji tingkat kesukaran hasilnya dapat dilihat pada Tabel 12.

Tabel 12. Hasil Uji Tingkat Kesukaran

\begin{tabular}{cccc}
\hline Status tingkat kesukaran & Butir soal & Jumlah & Persentase \\
\hline Sukar & $1,2,4,5,6,7,8,11,15,20,21,30$ & 12 & $40 \%$ \\
Sedang & $3,9,10,12,16,18,19,25,26,28$ & 10 & $33 \%$ \\
Mudah & $13,14,17,22,23,24,27,29$ & 8 & $27 \%$ \\
\hline
\end{tabular}

Berdasarkan dari tabel 12 dapat dilihat bahwa terdapat $40 \%$ soal berkategori sukar, $33 \%$ soal berkategori sedang dan $27 \%$ soal berkategori mudah. Menurut (Arikunto, 2019) bahwa soal yang baik adalah soal yang tidak terlalu mudah dan tidak terlalu sukar. Sudijono, (2015) menambahkan bahwa soal dalam kategori sedang dapat disimpan di bank soal, soal dalam kategori yang sukar dan mudah terdapat tiga kemungkinan yaitu di buang, direvisi atau disimpan dan digunakan kembali untuk campuran soal test. 
4) Daya Pembeda

Kemampuan suatu soal untuk dapat membedakan antara siswa yang menguasai materi dan yang tidak menguasai materi (Arikunto, 2019). Berikut hasil uji daya beda dalam penelitian ini dapat terlihat pada Tabel 13.

Tabel 13. Hasil Uji Daya Beda

\begin{tabular}{ccc}
\hline Daya Beda & Butir Soal & Jumlah \\
\hline Jelek & $2,6,7,9,20,22,25,26,30$ & 9 \\
Cukup & $3,4,10,11,12,13,14,15,16,18,19,21,28$ & 13 \\
Baik & $8,17,23,24,27,29$ & 6 \\
Negatif & 1,5 & 2 \\
\hline
\end{tabular}

Tindak lanjut dari uji daya pembeda pada instrument soal yang dikembangkan merujuk pada Rahayu \& Djazari, (2016) yaitu soal dengan daya beda yang cukup dan baik dapat digunakan, soal dengan kategori jelek perlu direvisi sedangkan soal dengan kategori negative dapat dibuang. Berdasarkan tabel 13 dapat dilihat bahwa terdapat 2 soal dalam kategori negative, sesuai yang dikemukakan oleh (Arikunto, 2019) bahwa jika indeks diskriminan menunjukkan kategori negative artinya soal tersebut tidak memiliki daya pembeda.

\section{SIMPULAN}

Literasi sains merupakan kompetensi yang amat penting yang harus dimiliki oleh siswa, literasi sains berguna bagi siswa dalam menyikapi fenomena-fenomena yang terjadi di kehidupan, baik berupa beraktivitas atau menyelesaikan masalah dengan mengimplementasikan pemahaman sains. Selain itu, literasi juga berperan agar mendidik siswa dalam bersikap bijak terhadap lingkungan. Berdasarkan hasil PISA Indonesia hingga saat ini masih setia berada pada posisi rendah untuk kategori literasi sains yang mana hal ini dapat tergambarkan dengan jelas pada pola prilaku orang-orang Indonesia. Selain itu berdasarkan analisis awal di SMP Kartika-X dan SMP PGRI 3 juga menunjukkan tingkat literasi sains siswa yang kurang. Oleh karena itu digalakanlah berbagai upaya agar dapat meningkatkan literasi sains yang salah satunya adalah pengembangan instrument. Pengembangan instrument ini melatih siswa untuk bertemu dan menyikapi kasuskasus di kehidupan dalam bentuk soal. Yang mana diharapkan dengan melatih siswa melalui instrument literasi maka kemampuan literasi siswa pun akan meningkat. Pengembangan instrument yang dilakukan oleh peneliti memiliki tingkat validitas logis oleh dua validator ahli yaitu $84,2 \%$, validitas empiris yang baik $76,67 \%$ serta reliabel pada skor 0,74 . Selain itu sebanyak $30 \%$ soal dalam kategori yang sedang (tidak sukar dan tidak mudah) serta terdapat 19 soal dengan daya beda yang cukup dan baik. 


\section{SARAN}

Saran dari peneliti untuk kegiatan penelitian selanjutnya yaitu penelitian ini dapat dikembangkan dengan menggunakan penilaian formatif seperti asesmen autentik. Selain itu diharapkan butir-butir instrument yang dikembangkan dapat diterapkan dalam penilaian harian sehingga dapat lebih banyak kesempatan untuk meningkatkan literasi sains siswa.

\section{UCAPAN TERIMA KASIH}

Ucapan terima kasih kami sampaikan kepada tim, validator ahli Dr. Irdalisa, S.Si, M.Pd \& Sawukirnadi, S.Pd. serta SMP Kartika 1 dan SMP PGRI 3 Kota Bekasi.

\section{REFERENSI}

Adawiyah, R., \& Wisudawati, A. W. (2017). Pengembangan Instrumen Tes Berbasis Literasi Sains: Menilai Pemahaman Fenomena Ilmiah Mengenai Energi. Indonesian Journal of Curriculum, 5(2), 112-121. http://dx.doi.org/10.15294/ijcets.v3i1.8675

Afriana, J., Permanasari, A., \& Fitriani, A. (2016). Implementation Project-Based Learning Integrated STEM to Improve Scientific Literacy Based on Gender. Jurnal Inovasi Pendidikan IPA, 2(2), 202-212. http://dx.doi.org/10.21831/jipi.v2i2.8561

Akbar, S. (2013). Instrumen Perangkat Pembelajaran. Remaja Rosdakarya.

Arikunto, S. (2019). Dasar-Dasar Evaluasi Pendidikan. Bumi Aksara.

Asyhari, A. (2015). Profil Peningkatan Kemampuan Literasi Sains Siswa Melalui Pembelajaran Saintifik. Jurnal Ilmiah Pendidikan Fisika Al-Biruni, 4(2), 179-191. https://doi.org/10.24042/jpifalbiruni.v4i2.91

Berman, E. A., \& Kuden, J. L. (2017). Scientific Literacy. In Agriculture to Zoology: Information Literacy in the Life Sciences. Daria O. Carle, Julianna E. https://doi.org/10.1016/B978-0-08100664-1.00002-8

BouJaoude, S. (2002). Balance of scientific literacy themes in science curricula: The case of Lebanon. International Journal of Science Education, 24(2), 139-156. https://doi.org/10.1080/09500690110066494

Chiappetta, E. L., Fillman, D. A., \& Sethna, G. H. (1991). A method to quantify major themes of scientific literacy in science textbooks. Journal of Research in Science Teaching, 28(8), 713-725. https://doi.org/10.1002/tea.3660280808

Chusnani, D. (2013). Pendidikan Karakter Melalui Sains. Jurnal Kebijakan Dan Pengembangan Pendidikan, 1(1), 9-13. https://doi.org/10.22219/jkpp.v1i1.1502

Fensham, P. J. (2009). Real world contexts in PISA science: Implications for context-based science education. Journal of Research in Science Teaching, 46(8), 884-896. https://doi.org/10.1002/tea.20334

Fibula Purnama, I Made Putrawan, \& Diana Vivanti Sigit. (2020). Pengaruh Pengetahuan Mengenai Isu-Isu Lingkungan (Knowledge About Environmental Issues) dan Intensi Untuk Bertindak (Intention to Act) terhadap Perilaku Bertanggung Jawab Lingkungan (Responsible Environmental Behavior) Siswa. IJEEM - Indonesian Journal of Environmental Education and Management, 5(1), 20-33. https://doi.org/10.21009/ijeem.051.02

Fraenkel, J., Wallen, N., \& Hyun, H. (2009). How to design and evaluate research in education (7th 
ed.). McGraw-Hill Companies.

Fuadi, H., Robbia, A. Z., Jamaluddin, J., \& Jufri, A. W. (2020). Analisis Faktor Penyebab Rendahnya Kemampuan Literasi Sains Peserta Didik. Jurnal Ilmiah Profesi Pendidikan, 5(2), 108-116. https://doi.org/10.29303/jipp.v5i2.122

Glick, M., \& Greenberg, B. L. (2017). A march toward scientific literacy. Journal of the American Dental Association, 148(8), 543-545. https://doi.org/10.1016/j.adaj.2017.06.010

Hazen. (2002, November 21). Why should you be scientifically literate. ActionBioscience. Org Is a Resource of the American Institute of Biological Sciences.

Holbrook, J., \& Rannikmae, M. (2009). The meaning of scientific literacy. International Journal of Environmental and Science Education, 4(3), 275-288. https://www.researchgate.net/publication/254162731_The_Meaning_of_Scientific_Litera cy

Ihsan, H. (2015). Validitas Isi Alat Uukur Penelitian: Konsep Dan Panduan Penilaiannya. $\begin{array}{lllll}\text { PEDAGOGIA Jurnal Ilmu } & 173 .\end{array}$ https://doi.org/10.17509/pedagogia.v13i3.6004

Mullis, I. V., Martin, M. O., Minnich, C. A., Stanco, G. M., Arora, A., Centurino, V. A., \& Castle, C. E. (2012). TIMSS 2011 Encyclopedia: Education Policy and Curriculum in Mathematics and Science. In Pirls (Vol. 1). https://files.eric.ed.gov/fulltext/ED544563.pdf

Nana, S. (2014). Penilaian Hasil Proses Belajar Mengajar. PT Remaja Rosdakarya.

OECD. (2016). PISA 2015 Assessment and analytical framework: mathematics, reading, science, problem solving and financial literacy. OECD Publishing.

OECD. (2018). PISA Result in Focus.

OECD. (2020). PISA 2018 Global competences. In The Ministry of Education: Vol. I. https: $/ /$ moe.go.kr/boardCnts/view.do?boardID=294\&lev=0\&statusYN=W\&s=moe\&m= 0204\&opType $=$ N\&boardSeq $=79191$

Ózdem, Y., Çavaş, P., Çavaş, B., Çakiroğlu, J., \& Ertepinar, H. (2010). An investigation of elementary students' scientific literacy levels. Journal of Baltic Science Education, 9(1), 6-19.

Putrawan, I. M. (2021). Prinsip-prinsip logis metodologi penelitian kuantitatif. CV Sadari.

Rahayu, R., \& Djazari, M. (2016). Analisis Kualitas Soal Pra Ujian Nasional Mata Pelajaran Ekonomi Akuntansi. Jurnal Pendidikan Akuntansi Indonesia, 14(1). https://doi.org/10.21831/jpai.v14i1.11370

Sellar, S., \& Lingard, B. (2014). The OECD and the expansion of PISA: New global modes of governance in education. British Educational Research Journal, 40(6), 917-936. https://doi.org/10.1002/berj.3120

Septiani, D., Widiyawati, Y., \& Nurwahidah, I. (2019). Pengembangan Instrumen Tes Literasi Sains Berbasis Pisa Pada Aspek Menjelaskan Fenomena Ilmiah Untuk Siswa Kelas Vii. Science Education and Application Journal, 1(2), 46. https://doi.org/10.30736/seaj.v1i2.144

Setiawan, A. R. (2019). Assimilation: Indonesian Journal of Biology Education Instrumen Penilaian untuk Pembelajaran Ekologi Berorientasi Literasi Saintifik (Assessment for Ecological Learning with Scientific Literacy Oriented). Assimilation, 7260(2), 42-46. homepage: http://ejournal.upi.edu/index.php/asimilasi

Sudijono, A. (2015). Pengantar Evaluasi Pendidikan. PT Raja Grafindo Persada.

Sugiyono. (2019). Metode Penelitian Kuantitatif Kualitatif dan R\&D. Alfabeta.

Sulistiawati. (2015). Analisa Pemahaman Literasi Sains Mahasiswa yang Mengambil Mata Kuliah IPA Terpadu menggunakan Contoh Soal PISA 2009. Sainteks, XII(1), 21-40. https://doi.org/10.30595/sinteks.v12i1.84

Sutrisna, N. (2021). Analisis Kemampuan Literasi Sains Peserta Didik SMA di Kota Sungai 
Penuh. Jurnal Inovasi Penelitianitian, 1(12), 2683. https://doi.org/10.47492/jip.v1i12.530

Thiagarajan, S. Semmel, D. S \& Semmel, M. (1974). Instructional development for training teachers of exceptional children: A sourcebook. Journal of School Psychology, 14(1), 75. https://doi.org/10.1016/0022-4405(76)90066-2

Turiman, P., Omar, J., Daud, A. M., \& Osman, K. (2012). Fostering the 21st Century Skills through Scientific Literacy and Science Process Skills. Procedia - Social and Behavioral Sciences, 59, 110-116. https://doi.org/10.1016/j.sbspro.2012.09.253

Zainal, A. (2012). Penelitian Pendidikan: Metode dan Paradigma Baru. Remaja Rosdakarya. 


\section{Lampiran 1. Instrumen Test Literasi Sains pada Materi Pencemaran Lingkungan}

\begin{tabular}{|c|c|}
\hline No. & Indikator \\
\hline & Pengetahuan \\
\hline 2 & 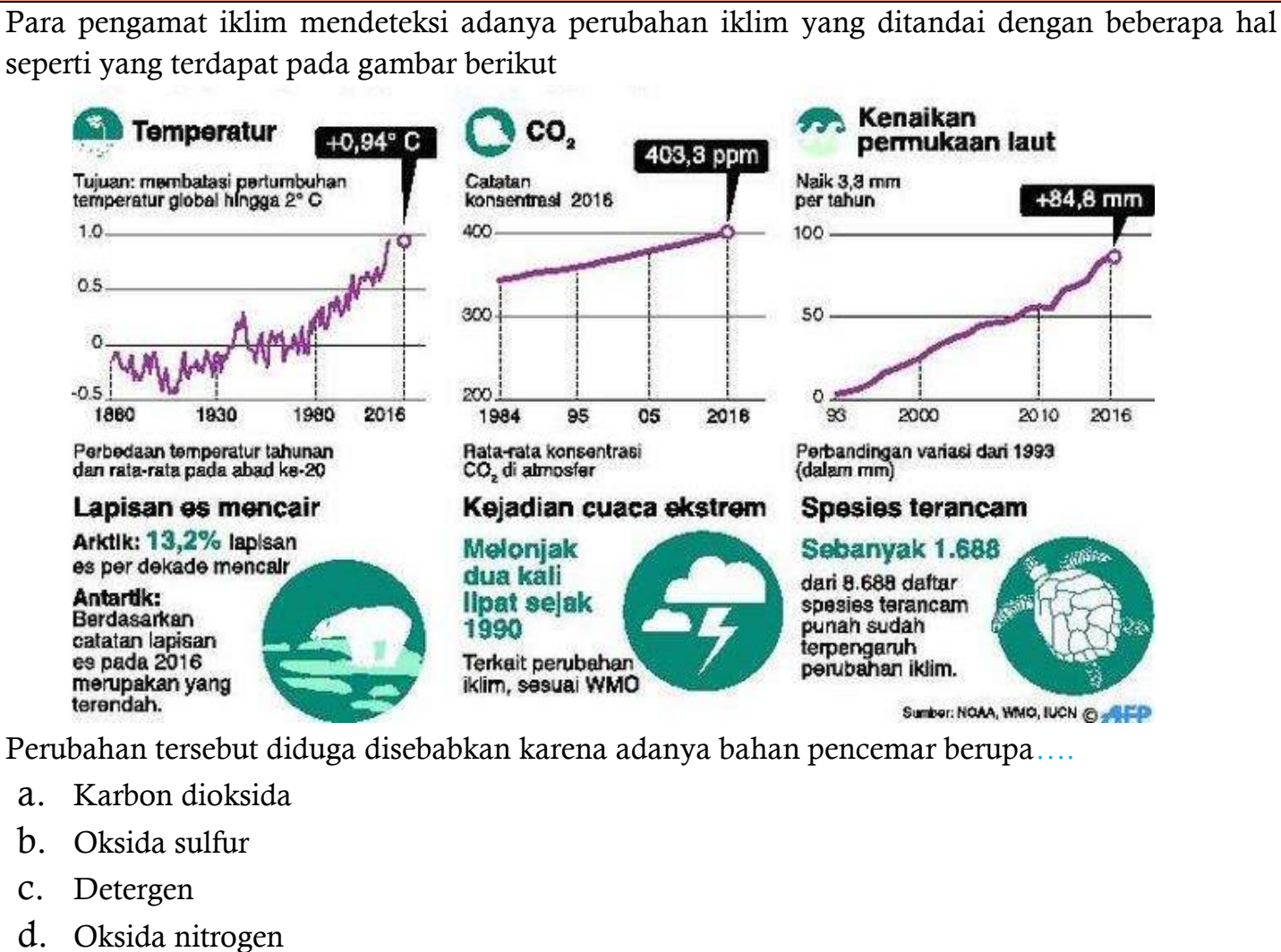 \\
\hline 3 & $\begin{array}{l}\text { Apabila terjadi peningkatan akumulasi } \mathrm{CO}_{2} \text { di atmosfer sehingga menyebabkan efek rumah kaca } \\
\text { seperti yang di ilustrasikan gambar diatas, maka perubahan dan dampak yang akan terjadi } \\
\text { adalah.. } \\
\text { a. radiasi sinar Matahari yang diserap Bumi berkurang sehingga suhu di permukaan bumi akan } \\
\text { menurun } \\
\text { b. radiasi sinar Matahari hanya sampai atmosfer Bumi sehingga suhu atmosfer meningkat } \\
\text { c. radiasi sinar Matahari yang dipantulkan Bumi tidak dapat menembus atmosfer sehingga suhu } \\
\text { Bumi meningkat } \\
\text { d. radiasi sinar Matahari yang dipantulkan atmosfer meningkat sehingga suhu ruang angkasa } \\
\text { meningkat }\end{array}$ \\
\hline 8 & $\begin{array}{l}\text { Salah satu langkah untuk meningkatkan hasil pertanian adalah dengan pembasmian hama } \\
\text { menggunakan insektisida seperti yang di ilustrasikan pada gambar berikut }\end{array}$ \\
\hline
\end{tabular}




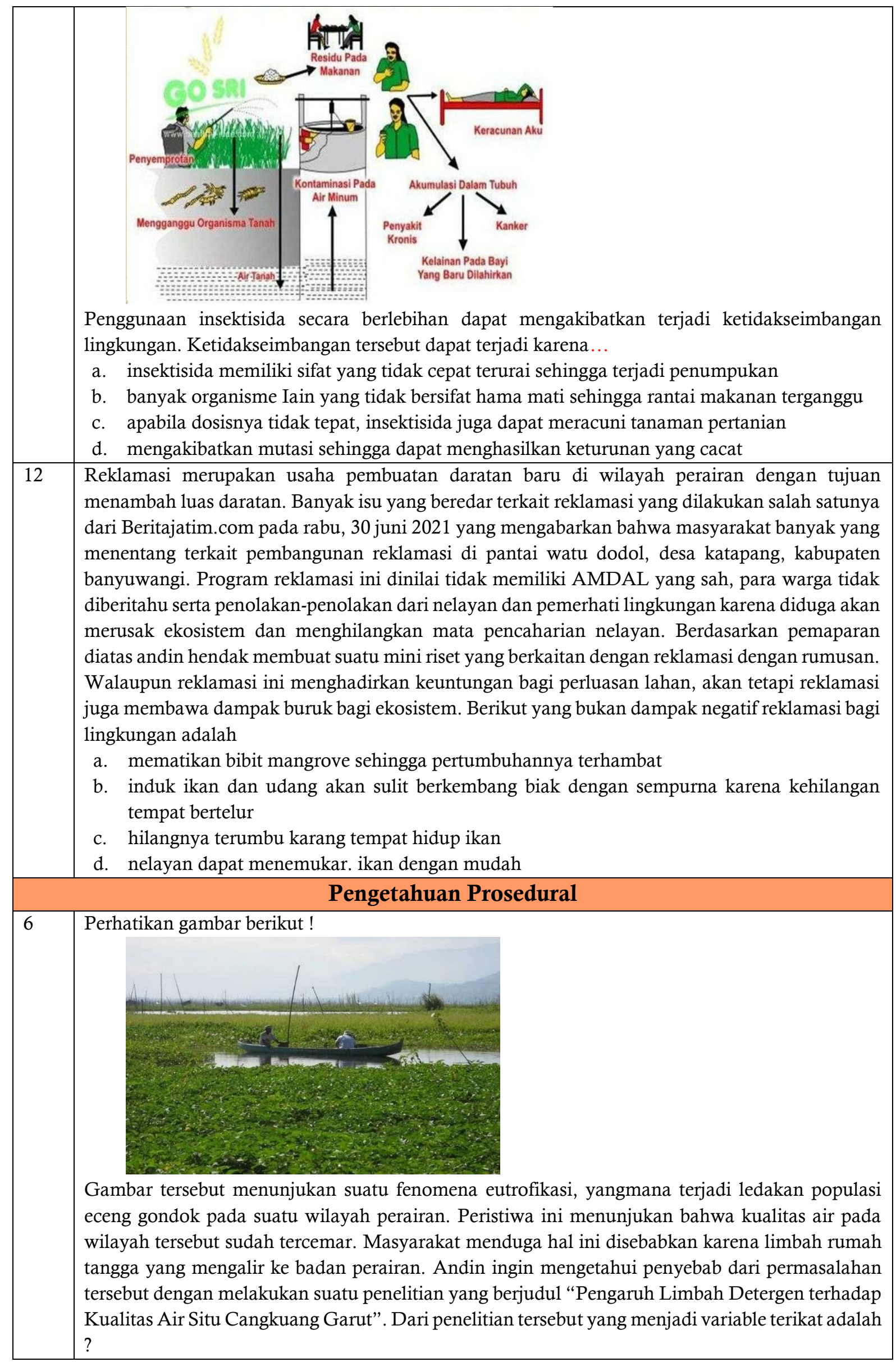




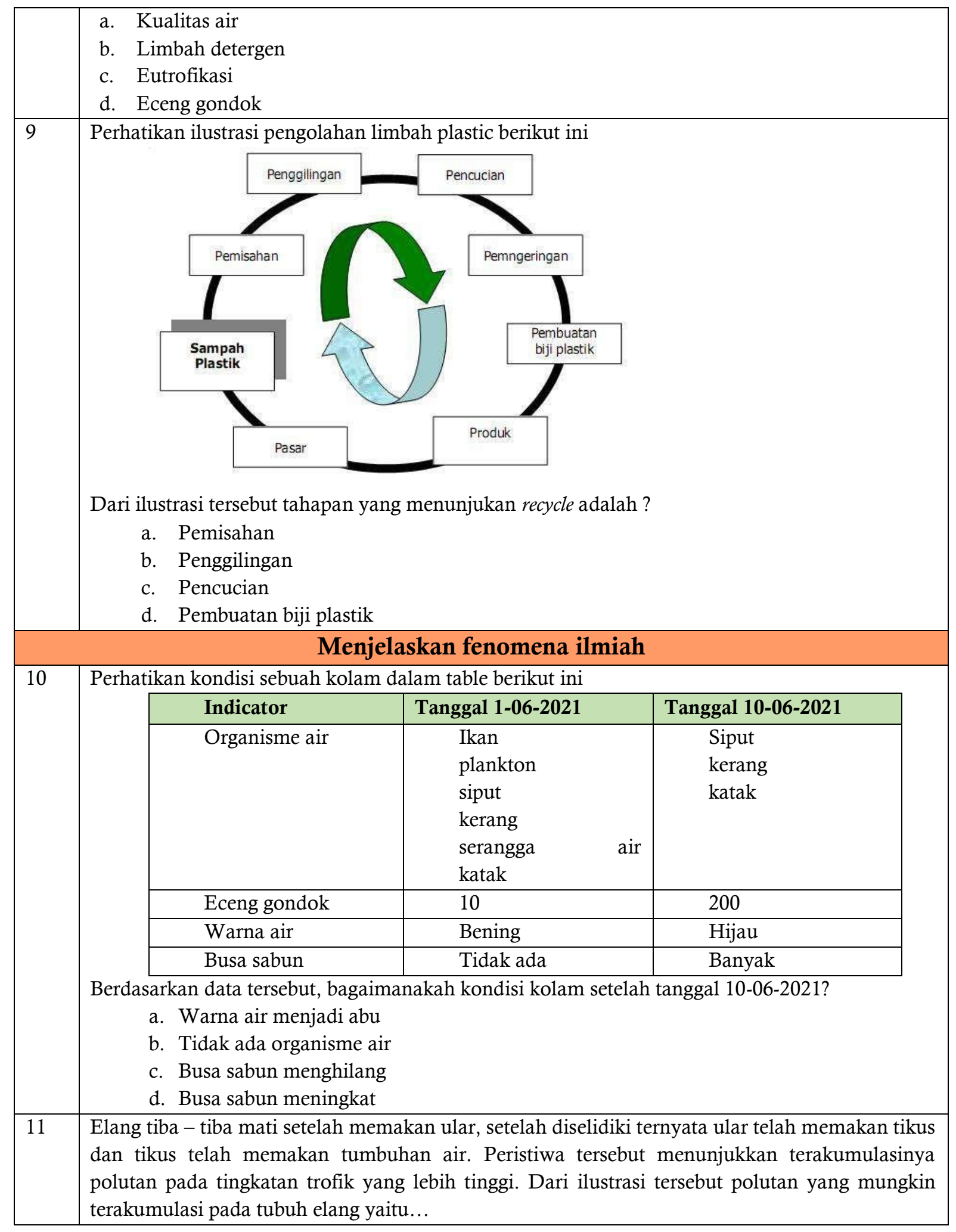




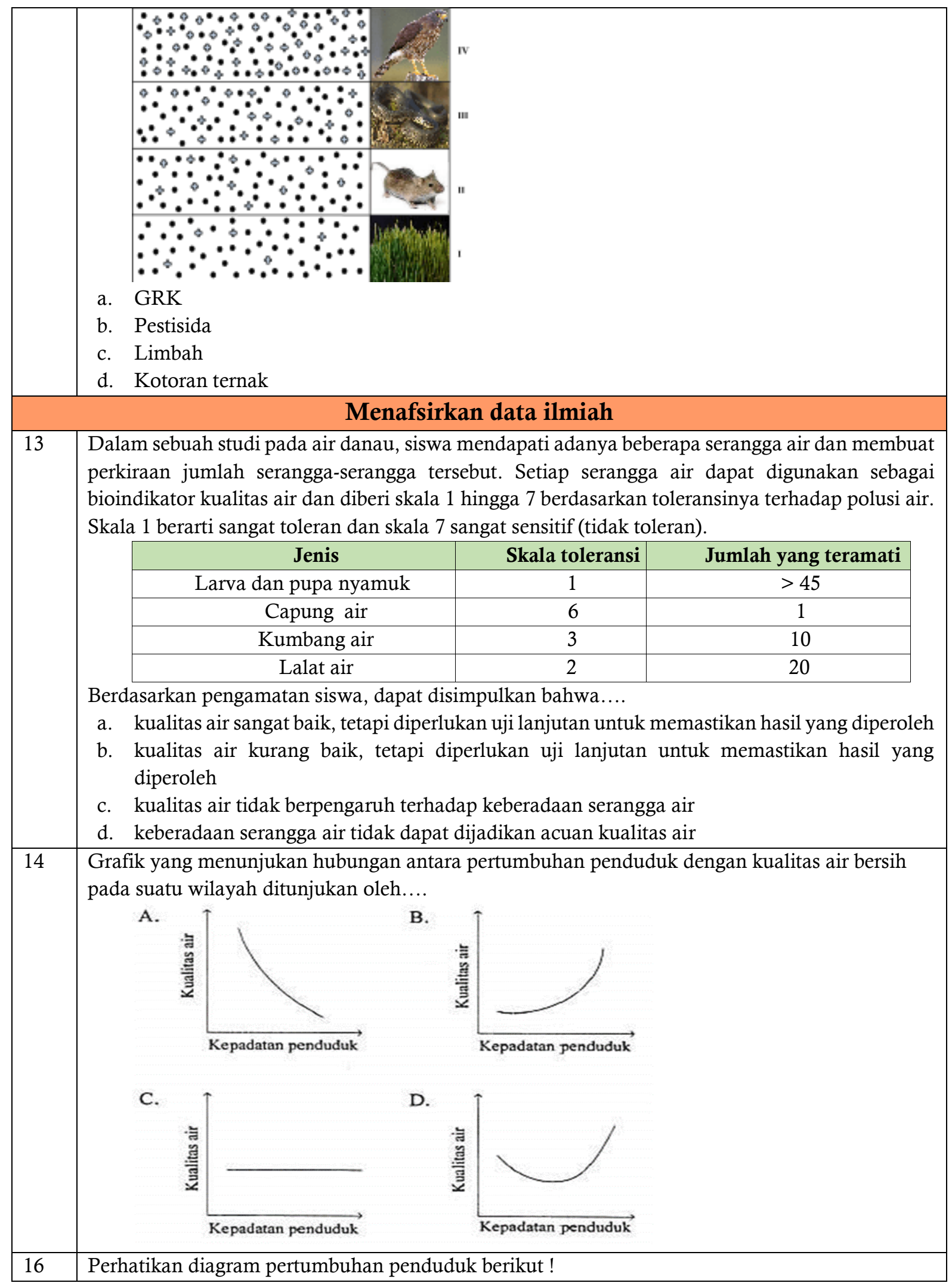




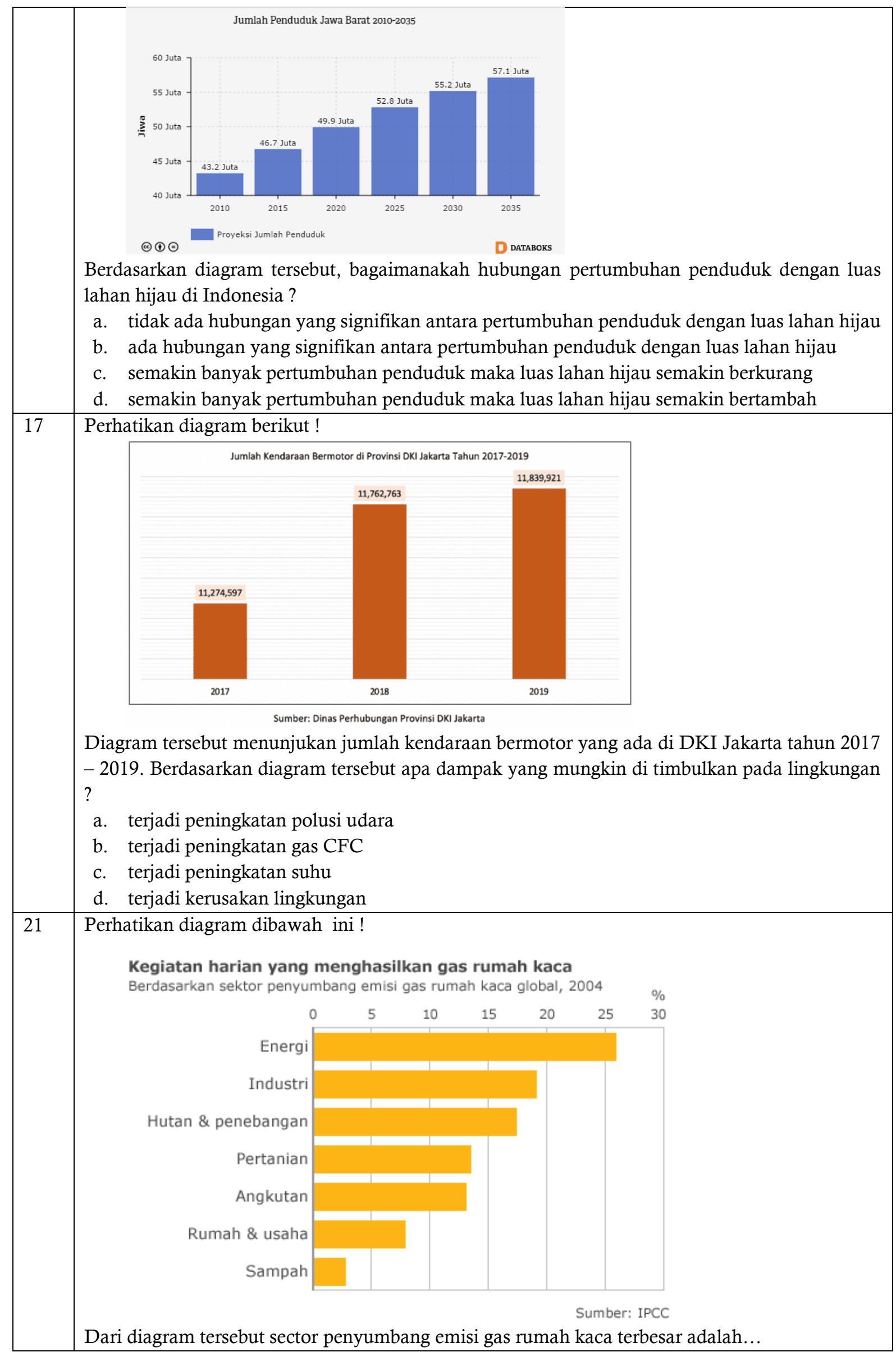




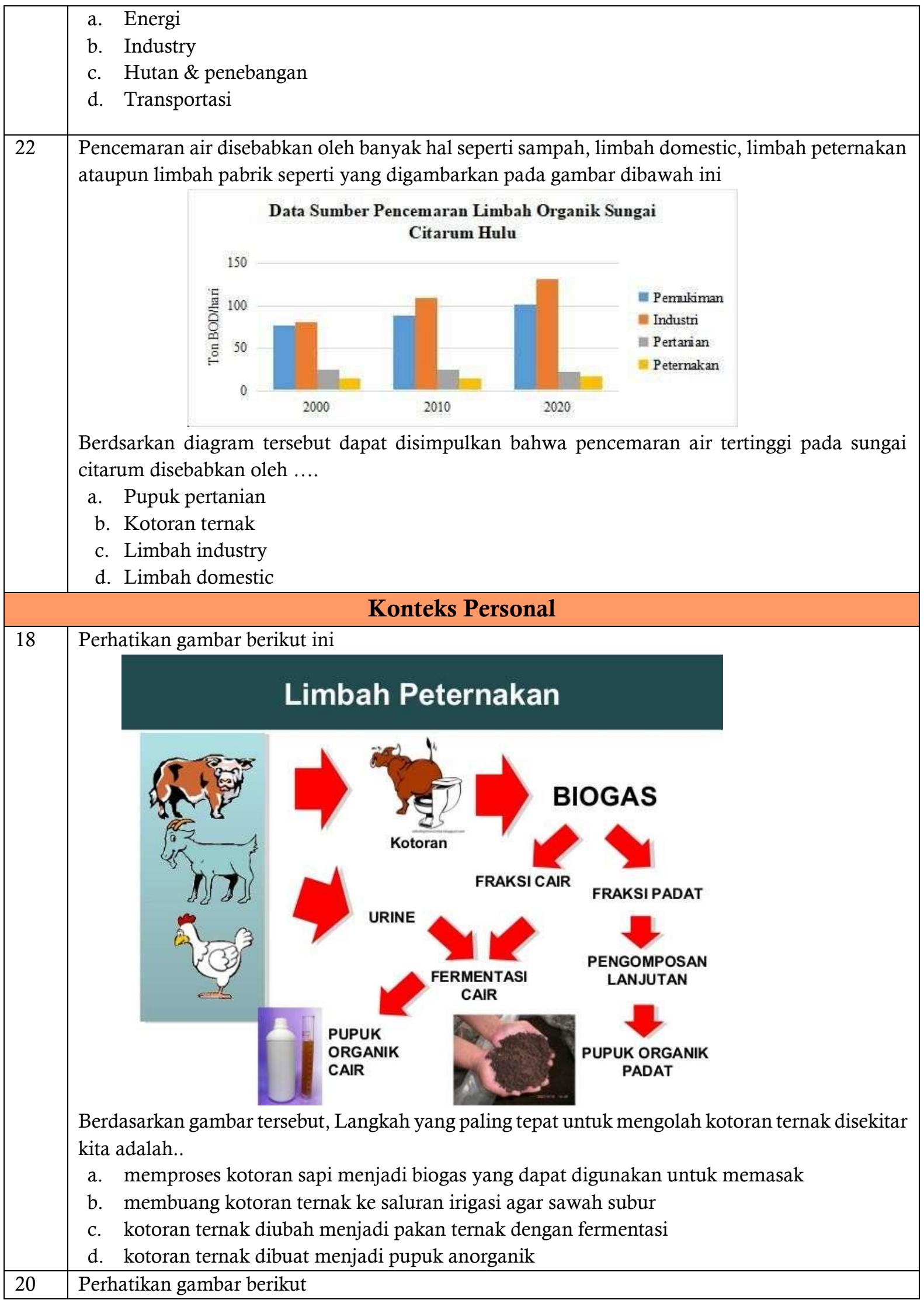




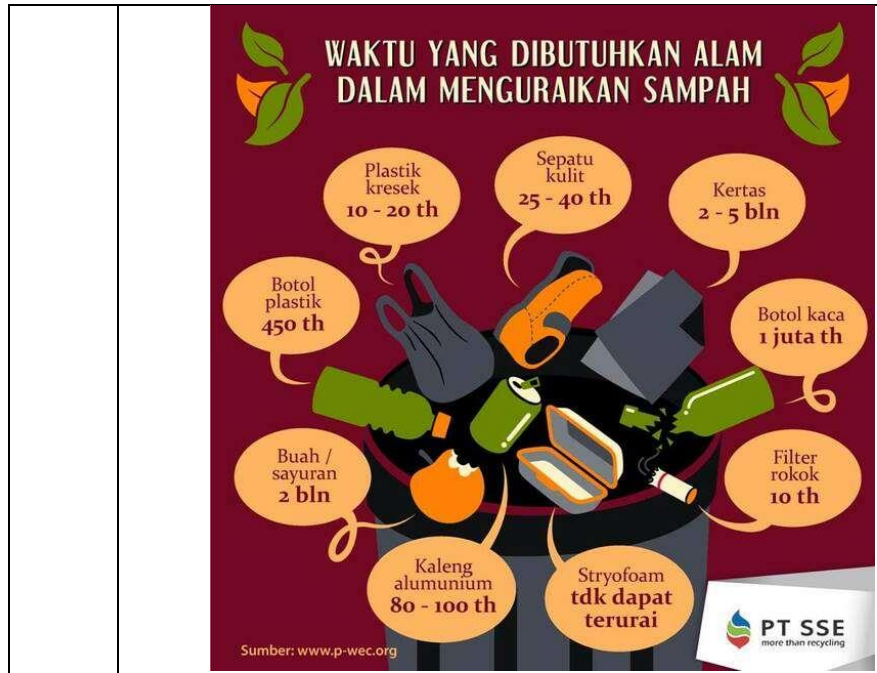

Berdasarkan ilustrasi tersebut menunjukan bahwa alam memiliki waktu yang sangat lama untuk menguraikan sampah-sampah non-organik seperti sepatu, kaca, plastic, botol, kaleng dll, bahkan ada yang tidak dapat sama sekali diuraikan oleh alam seperti stryofoam. Cara yang bisa kita gunakan untuk menanggulangi sampah yang sulit diuraikan oleh alam yaitu dengan....

a. memberi sanksi kepada setiap pembeli yang meminta kantong plastik

b. sampah non-organik sebaiknya dikubur di dalam tanah

c. menggunting plastik menjadi potongan - potongan kecil sebelum dibuang

d. mendaur ulang sampah non-organik sehingga dapat dimanfaatkan lagi

\begin{tabular}{|c|c|}
\hline \multicolumn{2}{|r|}{ Konteks Lingkungan } \\
\hline 23 & $\begin{array}{l}\text { Sumber: } \\
\text { https://www.kompasiana.com/hendychewadinata/5e } 46517 \mathrm{bd} 541 \mathrm{df} 75 \mathrm{bd} 2 \mathrm{bd} 3 \mathrm{~d} 2 / \text { cintai-dan- } \\
\text { hargai-alam-dengan-tidak-buang-sampah-sembarangan } \\
\text { dari laporan tersebut apakah factor yang mendasari masyarakat terus membuang sampah ke } \\
\text { sungai? } \\
\text { a. Karena tidak ada tempat penampungan sampah } \\
\text { b. Tidak ada larangan membuang sampah ke sungai } \\
\text { c. Agar sampah tidak menumpuk di jalan } \\
\text { d. Sungai tersebut tidak digunakan sebagai sumber air minum }\end{array}$ \\
\hline 25 & $\begin{array}{l}\text { Fenomena sampah bukanlah suatu hal yang tabu untuk di perbincangkan, sampah sudah } \\
\text { bertahun-tahun menjadi isu nasional bagi negeri ini. Tumpukan-tumpukan sampah sudah mulai } \\
\text { membentuk bukit dan mencemari area disekitarnya, cara penanggulangan akibat pencemaran }\end{array}$ \\
\hline
\end{tabular}




\begin{tabular}{|c|c|}
\hline 26 & 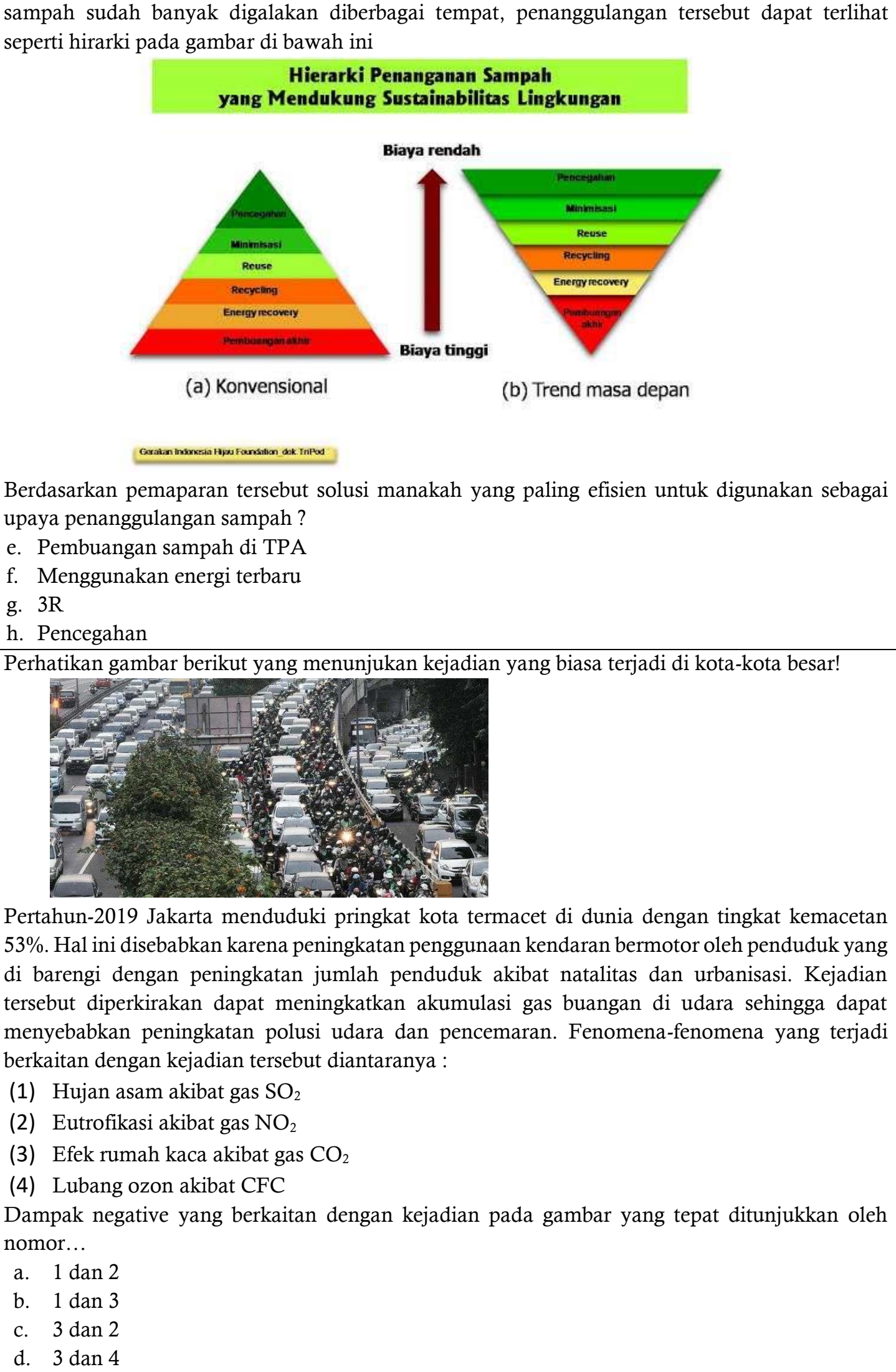 \\
\hline & Sikap - Kesadaran Lingkungan \\
\hline 27 & Perhatikan gambar dibawah ini \\
\hline
\end{tabular}




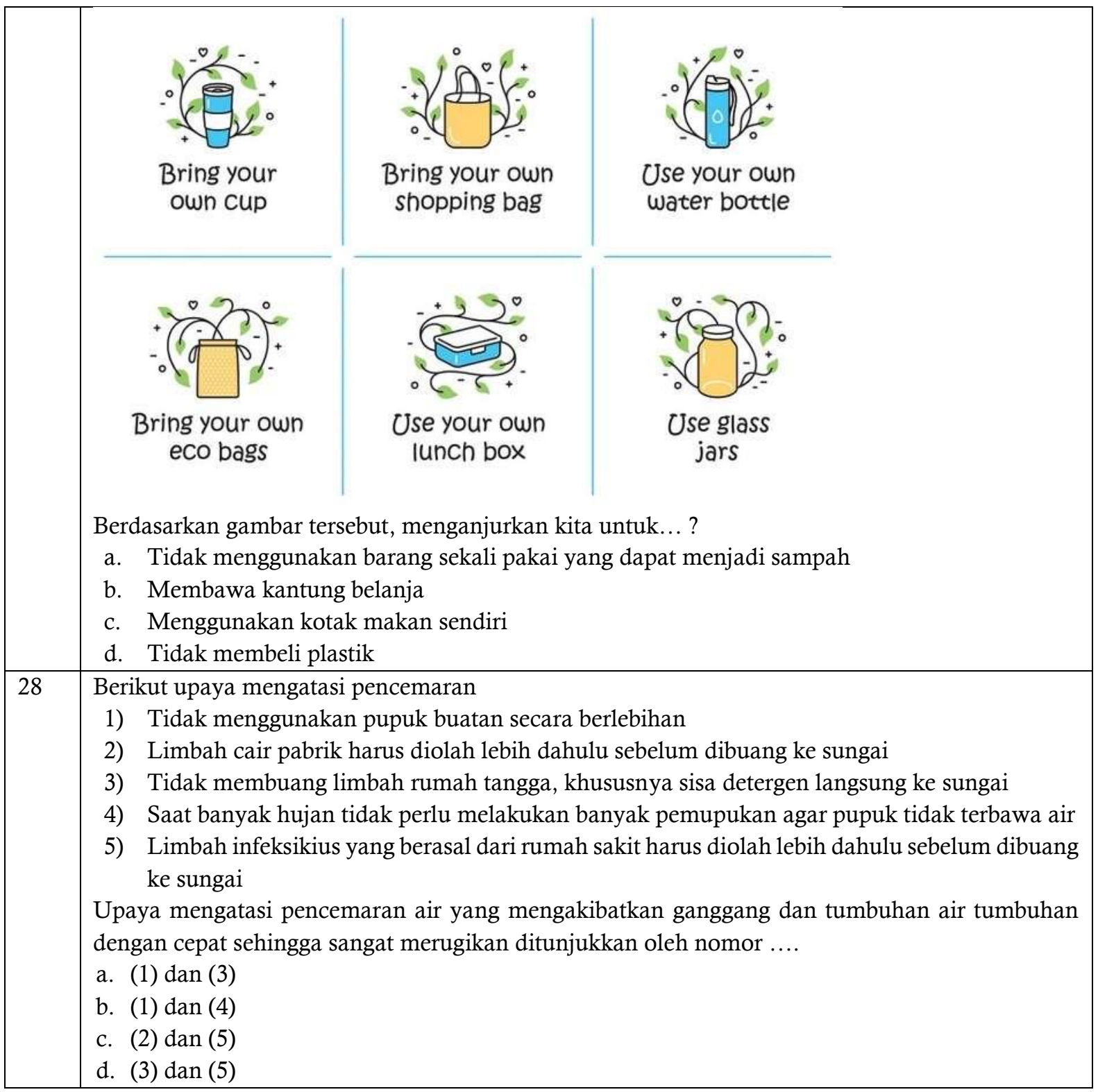

\section{Keterangan :}

1. Jumlah butir soal berdasarkan hasil validasi dengan rumus point biserial berjumlah 23 soal yang valid dari 30 soal.

2. Soal hasil analisis uji taraf kesukaran dan daya beda dengan kategori yang masih dapat diperbaiki sudah di perbaiki.

3. Terdapat dua soal yang tidak memiliki daya pembeda atau daya bedanya negative maka soal tersebut di buang yaitu soal nomor 29 dan 30 . 